\title{
The effect of heat treatment on the structure and corrosion resistance of $\mathrm{Al}-\mathrm{Zn}-\mathrm{Mg}$ alloys
}

\author{
Wojciech Jurczak, Ph. D. \\ Polish Naval Academy
}

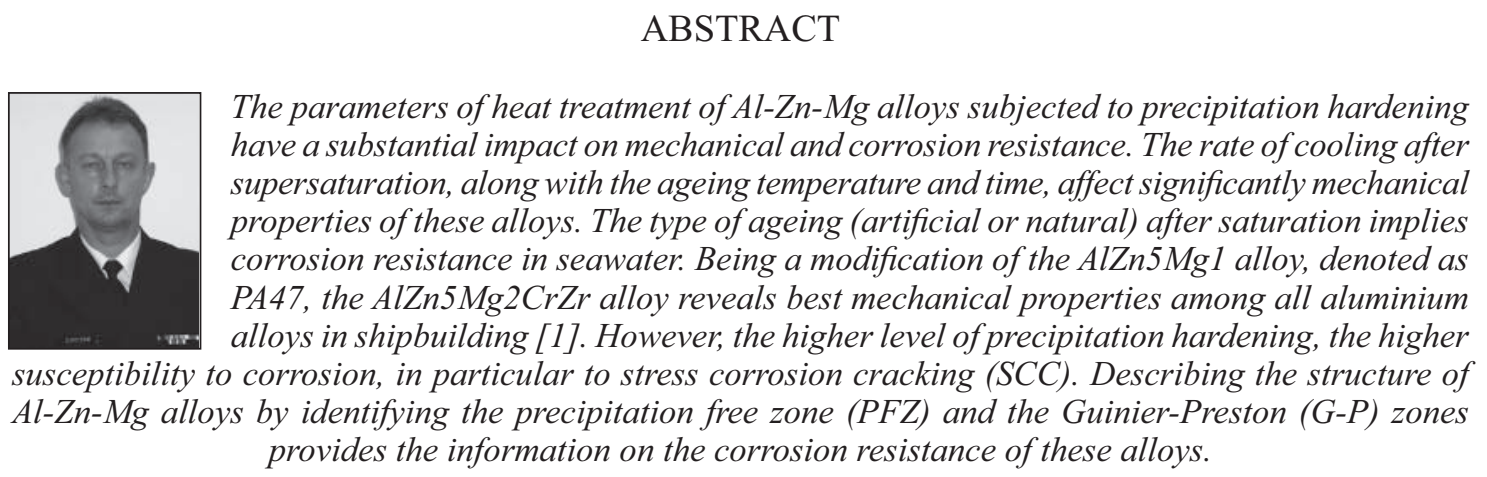

Keywords: Aluminium alloys, structure, corrosion resistance, precipitation hardening

\section{INTRODUCTION}

$\mathrm{Al}-\mathrm{Zn}-\mathrm{Mg}$ alloys for heat treatment which are used in shipbuilding are hardened by fine-dispersion precipitation products. Effective hardening of the aluminium alloys consists in the introduction of strange atoms and dislocations to the basic metal lattice, an effect of thermal processing, and in the creation of a sufficient number of fine-dispersion coherent phase or intermetallic compound precipitation products having the form of small particles. In order to secure high volumetric contribution of the precipitation products, they should form in the lattice of the basic metal and, if possible, beyond the grain boundaries and other defects of the crystal structure, as these defect decrease the potential barrier of nucleation, this way becoming the privileged places for precipitation of secondary heterogeneous phases $[2,3]$.

Heat treatment of Al-Zn-Mg alloys comprises supersaturation and ageing processes. The supersaturation, which consists in soaking the alloy in the solid-solution phase (within the solubility limit range) in a well-defined time, is the first stage, after which fast cooling takes place. Unlike Al-Mg alloys, the $\mathrm{Al}-\mathrm{Zn}-\mathrm{Mg}$ alloys are subjected to the process of ageing (natural or artificial), which is possible due to the presence of $\mathrm{Zn}$ or $\mathrm{Mg}$ atoms in the solid solution lattice. Zinc reveals varying, temperature dependent solubility in solid state, and the rate of precipitation of phases of $\mathrm{MgZn}_{2}, \mathrm{Al}_{3} \mathrm{Mg}_{2}, \mathrm{Al}_{2} \mathrm{Mg}_{3} \mathrm{Zn}_{3}$ type should be selected in such a way that they remain in the solid solution in the form of fine phases during the cooling process. The temperature of ageing determines the type and structure of the precipitated phases [4].
In practice, however, the stability of properties of Al-Zn-Mg alloys, including their corrosion and tribological resistance, strongly differs from sample to sample, as it depends on the technological production and processing time-history and the conditions in which particular machine and construction elements are used and operated.

Taking this into account, the effect of heat treatment parameters on the structure of the $\mathrm{AlZn} 5 \mathrm{Mg} 2 \mathrm{CrZr}$ alloy, and, consequently, its mechanical properties and corrosion resistance were examined experimentally. The article reports the results of this examination.

\section{CHARACTERISTICS OF THE EXAMINED MATERIAL}

The objects of examination were hot-rolled sheets of a new alloy AlZn5Mg2CrZr. The sheets were 6 and $12 \mathrm{~mm}$ thick and they were taken from two industrial melts 507. The chemical composition, heat treatment, and mechanical properties characteristic for four lots of sheets are given in Table 1. Ingots, having dimensions of $145 \times 450 \mathrm{~mm}$, were produced using the method of semi-continuous casting in the temperature of $\sim 700{ }^{\circ} \mathrm{C}$. The ingots were cut into parts $750 \mathrm{~mm}$ long and homogenised in the temperature of $480^{\circ} \mathrm{C}$ during 12 hours. The temperature in which the ingots were heated before rolling was $440-460{ }^{\circ} \mathrm{C}$. $12-14$ roll passes were done for sheets of $\mathrm{g}=12 \mathrm{~mm}$, while for sheets of $\mathrm{g}=6 \mathrm{~mm}$ the number of roll passes was equal to 20-24. The rolled sheets were cut to the dimension and passed to tb-type heat treatment. 
Tab. 1. Chemical composition of AlZn5Mg2CrZr tb alloy /certif. IMN-OML no. 4550/91.336 OML/91/

\begin{tabular}{|c|c|c|c|c|c|c|c|c|c|c|c|c|}
\hline No. of & \multicolumn{10}{c|}{ Chemical composition [\%] } & No. of lot and \\
\hline alloy & $\mathrm{Zn}$ & $\mathrm{Mg}$ & $\mathrm{Cr}$ & $\mathrm{Zr}$ & $\mathrm{Ti}$ & $\mathrm{Fe}$ & $\mathrm{Si}$ & $\mathrm{Cu}$ & $\mathrm{Mn}$ & $\mathrm{Ni}$ & $\mathrm{Al}$ & certificate \\
\hline 507 & 5.13 & 1.9 & 0.16 & 0.15 & 0.071 & 0.27 & 0.15 & 0.08 & 0.057 & 0.006 & remaining & 1085 \\
\hline \multicolumn{10}{|c|}{ tb - supersaturation - heating to $480{ }^{\circ} \mathrm{C}$ during 50 min., cooling with hot water of min. $70^{\circ} \mathrm{C}$} \\
natural ageing $0-4$ days in $20^{\circ} \mathrm{C}$, two-stage artificial ageing $-95^{\circ} \mathrm{C} / 8 \mathrm{~h}+150^{\circ} \mathrm{C} / 8 \mathrm{~h}$ \\
\hline
\end{tabular}

The properties of the examined $\mathrm{AlZn} 5 \mathrm{Mg} 2 \mathrm{CrZr}$ alloy were compared with those revealed by the PA47 alloy [5]*, whose chemical composition, given by the metallurgical certificate no. $2945 / 485 / 4$, is the following: $1.24 \% \mathrm{Mg}, 5.3 \% \mathrm{Zn}, 0.18 \% \mathrm{Mn}$, $0.034 \% \mathrm{Ti}, 0.14 \% \mathrm{Cr}, 0.16 \% \mathrm{Si}, 0.32 \% \mathrm{Fe}, 0.05 \% \mathrm{Cu}$, and the remaining $\mathrm{Al}$.

Tab. 2. Heat treatment parameters of AlZn5Mg2CrZr and PA47 alloys

\begin{tabular}{|c|c|c|c|c|c|c|}
\hline \multirow[b]{3}{*}{ No. } & \multirow[b]{3}{*}{ Alloy symbol } & \multirow[b]{3}{*}{ Melt } & \multicolumn{3}{|c|}{ Al-Zn-Mg alloy heat treatment parameters } & \multirow{3}{*}{$\begin{array}{c}\text { State } \\
\text { symbol }\end{array}$} \\
\hline & & & \multicolumn{2}{|c|}{ Solution heat treatment } & \multirow[b]{2}{*}{ Ageing type } & \\
\hline & & & $\begin{array}{l}\text { Temperature } \\
\text { and time }\end{array}$ & $\begin{array}{l}\text { Cooling after } \\
\text { solution heat } \\
\text { treatment }\end{array}$ & & \\
\hline 1 & $\begin{array}{c}\text { AlZn5Mg2CrZr } \\
\text { AlZn5Mg1* }\end{array}$ & 507 & $\begin{array}{c}\mathbf{4 5 0}{ }^{\circ} \mathbf{C} / \mathbf{1 . 5 h} \\
430^{\circ} \mathrm{C} / 45 \mathrm{~min}\end{array}$ & air $20^{\circ} \mathrm{C}$ & natural 100 days & ta \\
\hline 2 & $\begin{array}{c}\text { AlZn5Mg2CrZr } \\
\text { AlZn5Mg1* }\end{array}$ & 507 & $\begin{array}{c}\mathbf{4 5 0}{ }^{\circ} \mathbf{C} / \mathbf{1 . 5 h} \\
430^{\circ} \mathrm{C} / 45 \mathrm{~min}\end{array}$ & water $20^{\circ} \mathrm{C}$ & $\begin{array}{c}20^{\circ} \mathrm{C} / 6 \text { days }+ \\
\text { artificial ageing: } \\
95^{\circ} \mathrm{C} / 15 \mathrm{~h}+150{ }^{\circ} \mathrm{C} / 10 \mathrm{~h}\end{array}$ & $\mathrm{tb}_{21}$ \\
\hline 3 & $\begin{array}{c}\text { AlZn5Mg2CrZr } \\
\text { AlZn5Mg1* }\end{array}$ & 507 & $\begin{array}{c}\mathbf{4 5 0}{ }^{\circ} \mathbf{C} / \mathbf{1 . 5 h} \\
430^{\circ} \mathrm{C} / 45 \mathrm{~min}\end{array}$ & air $20^{\circ} \mathrm{C}$ & $\begin{array}{c}20^{\circ} \mathrm{C} / 6 \text { days }+ \\
\text { artificial ageing: } \\
95^{\circ} \mathrm{C} / 15 \mathrm{~h}+150{ }^{\circ} \mathrm{C} / 10 \mathrm{~h}\end{array}$ & $\mathrm{tb}_{23}$ \\
\hline 4 & $\begin{array}{c}\text { AlZn5Mg2CrZr } \\
\text { AlZn5Mg1* }\end{array}$ & 507 & $\begin{array}{c}\mathbf{4 5 0}{ }^{\circ} \mathbf{C} / \mathbf{1 . 5 h} \\
430^{\circ} \mathrm{C} / 45 \mathrm{~min}\end{array}$ & water $80^{\circ} \mathrm{C}$ & $\begin{array}{c}20{ }^{\circ} \mathrm{C} / 6 \text { days }+ \\
\text { artificial ageing: } \\
95{ }^{\circ} \mathrm{C} / 15 \mathrm{~h}+150{ }^{\circ} \mathrm{C} / 10 \mathrm{~h}\end{array}$ & $\mathrm{tb}_{22}$ \\
\hline
\end{tabular}

* reference alloy PA47

Homogeneous distribution of $\mathrm{Zn}$ and $\mathrm{Mg}$ atoms in the aluminium matrix lattice, an effect of the supersaturation, leads to the creation of vacancies in the lattice, the number of which depends on temperature. During the ageing, these vacancies provide opportunities for diffusion of $\mathrm{Zn}$ and $\mathrm{Mg}$ atoms which occupy points in the three-dimensional lattice of aluminium.

\section{THE EFFECT OF HEAT TREATMENT ON MECHANICAL PROPERTIES OF AL-ZN-MG ALLOYS}

Comparing the results obtained for a series of examined samples made it possible to recognise to which extent the modification of chemical composition of the AlZn5Mg2 $\mathrm{CrZr}$ alloy, which consisted in increasing the contents of $\mathrm{Cr}, \mathrm{Zr}$, Ti and reducing the contents of $\mathrm{Mn}$ with respect to the PA47 alloy, along with properly selected heat treatment, affects the mechanical properties of the alloy. At the increased total contents of $\mathrm{Zn}+\mathrm{Mg}$, the modification aimed at reducing the effect of the degree of dispersion of the selected phases on grain boundaries (GZ) and in the surrounding precipitation free zones (SWW), which in case of PA47 provoked a tendency to intensive corrosion.

For identical ageing conditions, it is the cooling method after supersaturation (cooling in cold water of $20^{\circ} \mathrm{C}$ ) which secures the highest mechanical properties of the examined AlZn5Mg2CrZr alloy.
Tab. 3. Mechanical properties of AlZn5Mg2CrZr and AlZn5Mg1 alloys by various type of heat treatment

\begin{tabular}{|c|c|c|c|}
\hline \multirow{2}{*}{$\begin{array}{c}\text { Alloy symbol } \\
\text { Type of heat } \\
\text { treatment }\end{array}$} & \multicolumn{3}{|c|}{ Mechanical properties } \\
\hline & $\begin{array}{c}\mathbf{R}_{\mathrm{m}} \\
{[\mathrm{MPa}]}\end{array}$ & $\begin{array}{c}\mathbf{R}_{0.2} \\
{[\mathrm{MPa}]}\end{array}$ & $\begin{array}{c}\mathbf{A}_{5} \\
{[\%]}\end{array}$ \\
\hline $\begin{array}{c}\text { AlZn5Mg2CrZr } \\
\text { ta } \\
\text { tb }_{21} \\
\text { tb }_{22} \\
\text { tb }_{23}\end{array}$ & $\begin{array}{l}423 \\
418 \\
480 \\
465 \\
381\end{array}$ & $\begin{array}{l}379 \\
258 \\
438 \\
418 \\
310\end{array}$ & $\begin{array}{r}14.3 \\
14.0 \\
9.2 \\
9.8 \\
11.5\end{array}$ \\
\hline $\begin{array}{c}\mathrm{AlZn} 5 \mathrm{Mg} 1^{*} \\
\mathrm{ta} \\
\mathrm{tb}_{21} \\
\mathrm{tb}_{22} \\
\mathrm{tb}_{23}\end{array}$ & $\begin{array}{l}310 \\
386 \\
401 \\
376 \\
358\end{array}$ & $\begin{array}{l}240 \\
242 \\
354 \\
319 \\
293\end{array}$ & $\begin{array}{l}13.1 \\
22.3 \\
17.9 \\
17.8 \\
14.3\end{array}$ \\
\hline
\end{tabular}

* reference alloy PA47

\section{THE EFFECT OF HEAT TREATMENT ON THE STRUCTURE OF THE ALZN5MG2CRZR ALLOY}

Figure 1a shows the structure of the non-recrystallized sheet after cold rolling All Al-Zn-Mg sheet samples reveal 
a typical fibrous texture, parallel to the rolling direction. Precise observation could also make it possible to notice separate recrystallized grains on the surfaces parallel and perpendicular to the rolling direction, better visible on the former surfaces, Fig. 1b, included as reference for comparison, shows the structure of the $\mathrm{AlZn} 5 \mathrm{Mg} 2 \mathrm{CrZr}$ alloy after annealing and rolling in relatively low temperatures [6].
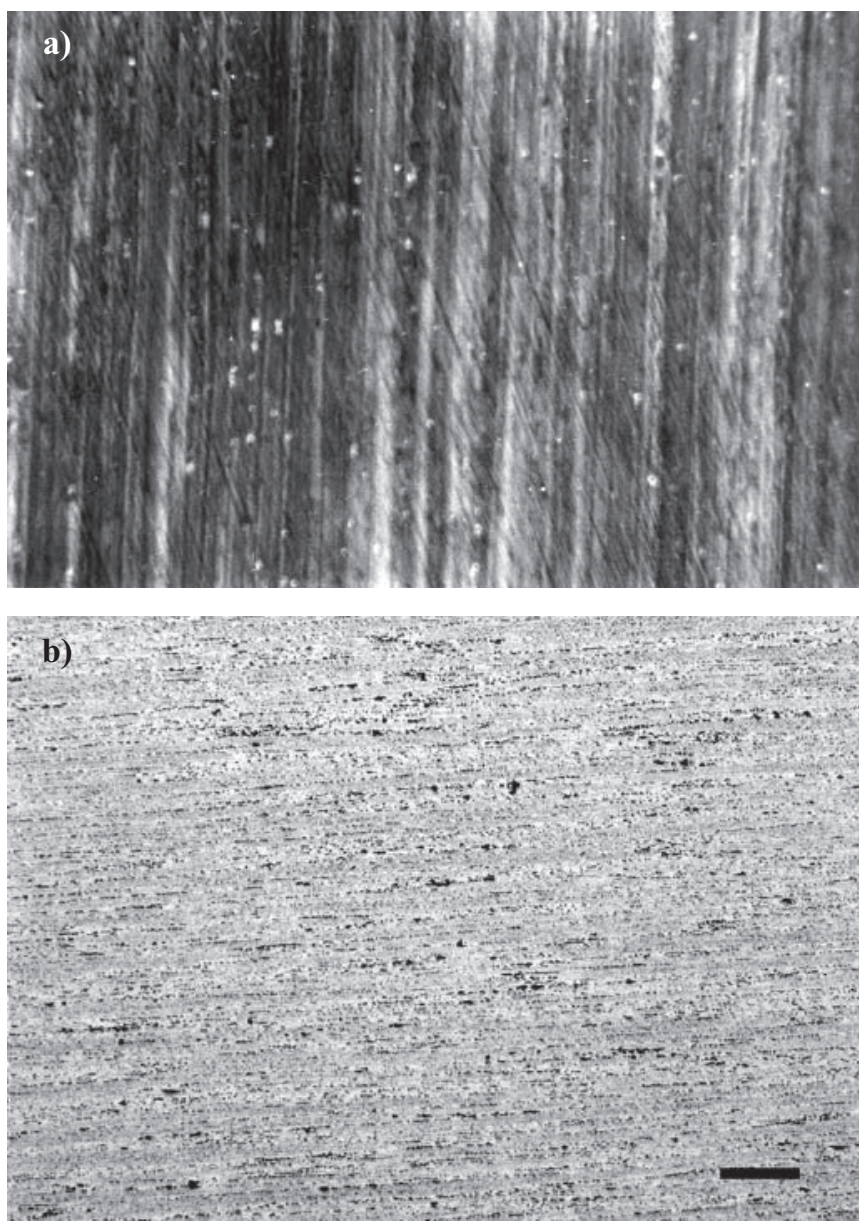

Fig. 1. Structure of the alloy: $\boldsymbol{a}$ - $\mathrm{AlZn} 5 \mathrm{Mg} 2 \mathrm{CrZr}$-T sheets $\mathrm{g}=12 \mathrm{~mm}$ in tb state, additionally oxidised in Backer's reagent, $100 x$ enlargement, and sample $\boldsymbol{b}$ - $\mathrm{AlZn} 5 \mathrm{Mg} 2 \mathrm{CrZr}-\mathrm{O}$ annealed by heat treating at $426^{\circ} \mathrm{C}$ for 3 hours, cooled at $20^{\circ} \mathrm{C}$ down to $232^{\circ} \mathrm{C}$ for 3 hours, then held at $232^{\circ} \mathrm{C}$ for 6 hours, and finally air cooled to room temperature. Etched with Keller's solution. Micron bar length was $100 \mathrm{~mm}$. The microstructure consists of random distribution of $\mathrm{Mg}(\mathrm{Zn}, \mathrm{Al},)_{2}$, and insoluble $\mathrm{FeAl}_{3}$

In $\mathrm{Al}-\mathrm{Zn}-\mathrm{Mg}$ alloys the following types of precipitation products are observed: large products randomly distributed in the metallic matrix, and G-P zones having the form of tweed structure. Beside the G-P zones, solid solution zones (SWW) are observed in direct vicinity of the boundaries of grains and subgrains. Larger products of $\mathrm{MgZn}_{2}$ precipitation are also observed at the grain boundaries.

The fibrous structure, characteristic for rolled products, is not homogeneous, as the degree to which alternately located fibres are enriched with $\mathrm{Cr}$ and $\mathrm{Ti}$ peritectics components is different. The origin of this heterogeneity is connected with the peritectic reactions of $\mathrm{Cr}$ and $\mathrm{Ti}$ taking place when the alloy solidifies. The products of the peritectic reaction, referred to as $\mathrm{Ti}$ and $\mathrm{Cr}$ atoms in the literature, collect in the centre of the dendritic cell, while peripheral parts of this cell clearly are visibly poorer in those elements [6,9]. Plastic working results in the appearance of separate bands which have more or less $\mathrm{Cr}$ and $\mathrm{Ti}$ atoms - bands which are richer and poorer in those elements lie alternately one on the other. If the differences in the concentration of those elements in adjacent bands are large and $\mathrm{Cr}$ and $\mathrm{Ti}$ are in the solid solution and not as finely dissipated separation particles connected with the peritectic reaction, then in case of corrosion attack the bands which are damaged first are those which are poor in $\mathrm{Cr}$ and $\mathrm{Ti}$, while the rich bands remain free of corrosion. The poor bands work as cathodes and the rich bands as anodes in the electrochemical micro corrosion cells. The corrosion takes an intercrystalline course along the bands which are parallel to the direction of plastic working. If the differences in the concentration of $\mathrm{Ti}$ and $\mathrm{Cr}$ elements are small, then the appearance of corrosion is limited, and it happens when $0,12-0.16 \%$ of zirconium is added to the alloy. The favourable structure is the structure with small dissipated products of $\mathrm{Cr}$ and Ti precipitation, which can be obtained by annealing the sheets in temperatures over $500^{\circ} \mathrm{C}$ for $\mathrm{Cr}$ and much higher for Ti. Thus the effect of Ti is clearly negative form the point of view of alloy sensitivity to interlayer corrosion. The precipitated $\mathrm{Mn}$ and Fe eutectics elements do not provoke corrosion themselves, but accelerate it in the presence of $\mathrm{Cr}$ and $\mathrm{Ti}$ atoms.

Figs 2-5 show the microstructures of the $\mathrm{AlZn} 5 \mathrm{Mg} 2 \mathrm{CrZr}$ alloy in heat treatment states ta, $\mathrm{tb}_{21}, \mathrm{tb}_{22}, \mathrm{tb}_{23}$.

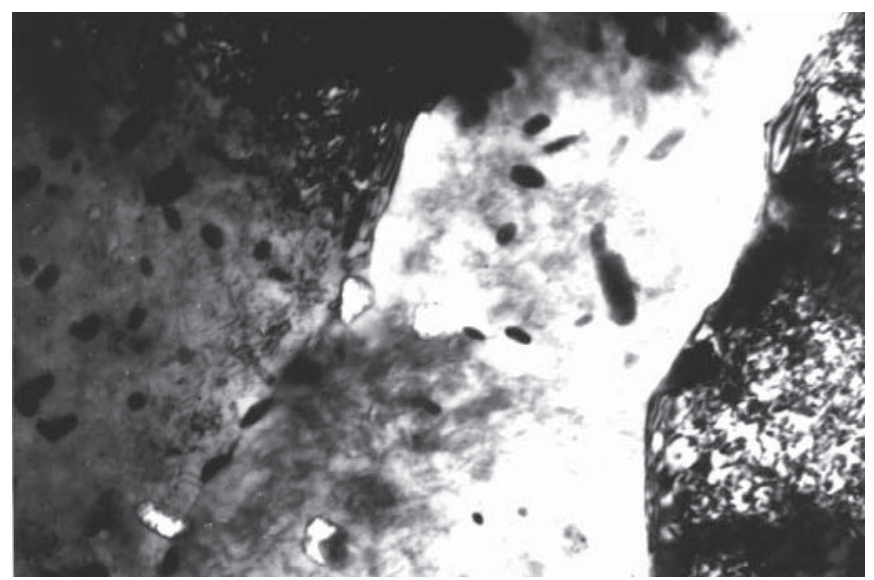

Fig. 2. Microstructure of AlZn5Mg2CrZr alloy state ta, TEM, thin foils. $47000 x$ enlargement

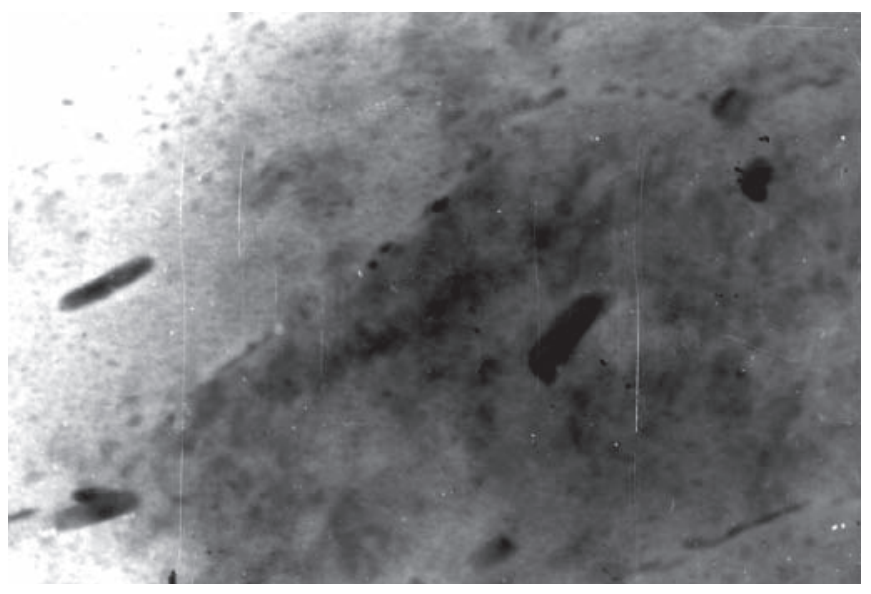

Fig. 3. Microstructure of AlZn5Mg2 CrZr alloy,

state $t b_{21}, T E M$, thin foil. 47000x enlargement

Tab. 4 collects SWW widths for the AlZn5Mg2CrZr alloy in different heat treatment states.

Tab. 4. SWW widths for AlZn5Mg2CrZr

alloy in different heat treatment states

\begin{tabular}{|c|c|c|c|c|}
\hline Heat treatment state & $\mathbf{t b}_{\mathbf{2 3}}$ & $\mathbf{t b}_{\mathbf{2 2}}$ & $\mathbf{t b}_{\mathbf{2 1}}$ & $\mathbf{t a}$ \\
\hline SWW [nm] & 400 & 180 & 95 & 60 \\
\hline
\end{tabular}




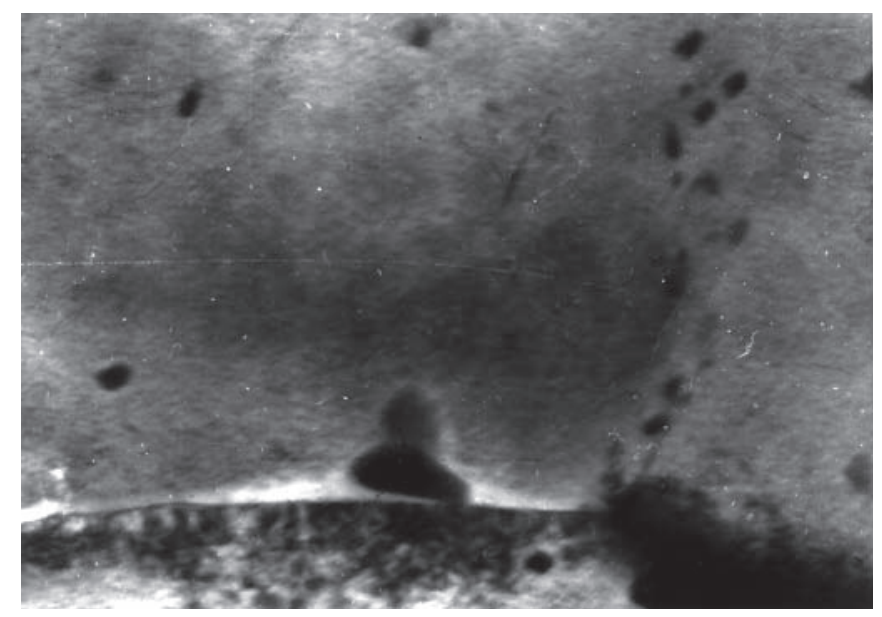

Fig. 4. Microstructure of AlZn5Mg2CrZr alloy, state $t b, T E M$, thin foil. 47.000x enlargement

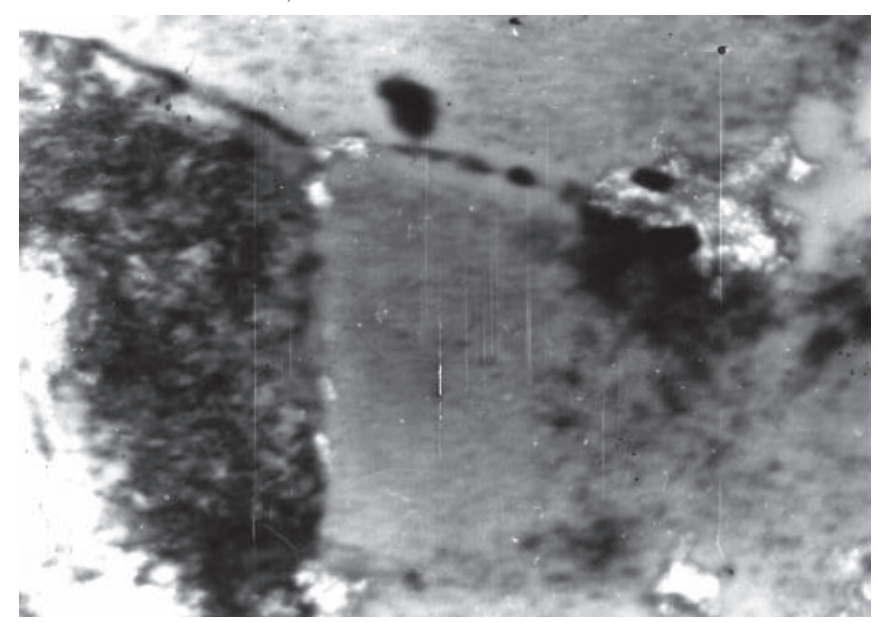

Fig. 5. Microstructure of AlZn5Mg2CrZr alloy, state $t b_{23}$, TEM, thin foils. 47.000x enlargement

The performed research has made it possible to detect clear dependence of the structure and mechanical properties of the $\mathrm{AlZn} 5 \mathrm{Mg} 2 \mathrm{CrZr}$ alloy on the heat treatment state. The $\mathrm{AlZn} 5 \mathrm{Mg} 2 \mathrm{CrZr}$ alloy in $\mathrm{tb}_{21}$ state revealed higher mechanical properties than in $\mathrm{tb}_{22}$ or $\mathrm{tb}_{23}$ state.

In the structure of the alloy obtained via rapid cooling in cold water after supersaturation and further artificial two-stage ageing, /state $\mathrm{tb}_{21} /$ the precipitation of G-P zones was observed. Identifying the G-P zones was done using selective electron diffraction and the material presented in [7]. The conclusion about their presence was drawn based on the so-called "tweed structure", which is the effect of the first decomposition of the solid solution. The observed precipitation free zones (SWW) are adjacent to grain boundaries of $50-80 \mathrm{~nm}$ in width. The factors which most affect the dimension of the SWW zones are the temperature and time of artificial ageing.

On the grain boundaries more intensive precipitation of the $\mathrm{MgZn}_{2}$ phase is observed. On the other hand, in samples cooled in the air after supersaturation /state $t_{23} /$ the decomposition of the solid solution was more advanced. Small amounts of transient phase $\eta^{\prime}$ and equilibrium phase $T$ precipitation products were observed. The latter phase most likely precipitated directly from the solid solution during slow cooling after supersaturation. The SWW zones of 340-420 nm in width were observed as well.

Fig. 6 shows the relation between the mechanical properties of the $\mathrm{AlZn} 5 \mathrm{Mg} 2 \mathrm{CrZr}$ alloy and the width of the SWW zone, when three types of cooling after supersaturation were used /cold water $20^{\circ} \mathrm{C}$, hot water $80^{\circ} \mathrm{C}$, air/. Increasing the rate of cooling after supersaturation results in the decrease of the SWW zone, accompanied by the increase of mechanical properties $/ \mathrm{R}_{\mathrm{m}}, \mathrm{R}_{0,2} /$.

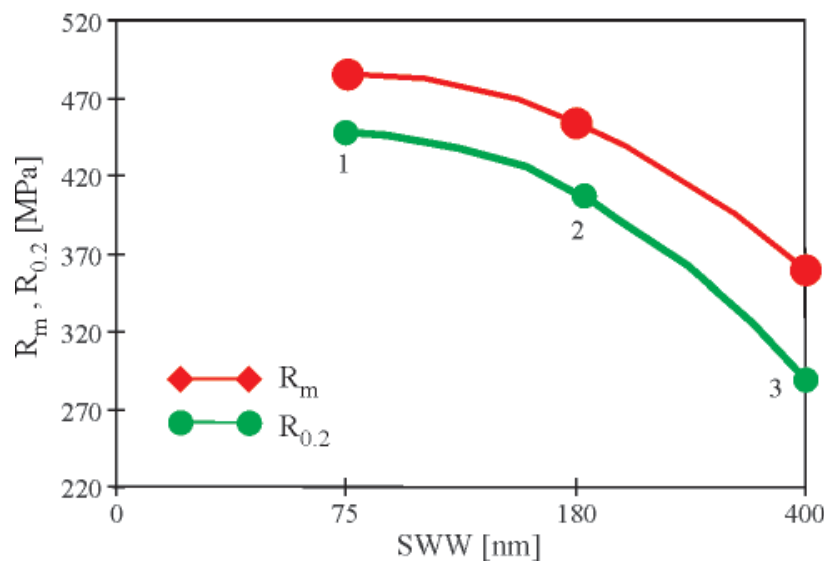

Fig. 6. Relation between $S W W$ zone width and mechanical properties of the AlZn5Mg2CrZr alloy, which after supersaturation was subjected to. 1 - slow cooling in cold water $/ T=20^{\circ} \mathrm{C} /-t b$

2 - cooling in hot water $/ T=80^{\circ} \mathrm{C} / \mathrm{tb} \mathrm{z}_{22}$,

3 - cooling in air - $t b_{23}$ and then subjected to two-stage ageing $-90^{\circ} \mathrm{C} / 8 \mathrm{~h}+145^{\circ} \mathrm{C} / 16 \mathrm{~h}$

Tab. 5. Description of AlZn5Mg2CrZr alloy microstructure in different heat treatment states

\begin{tabular}{|c|c|c|}
\hline No. & $\begin{array}{c}\text { AlZn5Mg2CrZr } \\
\text { alloy heat } \\
\text { treatment state }\end{array}$ & Microstructure description \\
\hline 1 & $\mathrm{t}_{\mathrm{a}}$ & $\begin{array}{c}\text { Phase } \eta \text { precipitation products } \\
\text { visible on grain boundaries }\end{array}$ \\
\hline 2 & $\mathrm{tb}_{21}$ & $\begin{array}{c}\text { Precipitation free zone adjacent } \\
\text { to grain boundaries is } 60-100 \\
\text { nm wide, and larger MgZn } \\
\text { phase precipitation products are } \\
\text { observed on grain boundaries }\end{array}$ \\
\hline 3 & $\mathrm{tb}_{22}$ & $\begin{array}{c}\text { Small products of transient } \\
\text { phase } \eta \text { 'precipitation are } \\
\text { observed inside the grains. } \\
\text { Phase } \eta \text { (MgZn } \text { ) precipitation } \\
\text { products, arranged in a number } \\
\text { of rows, are observed on grain } \\
\text { boundaries. }\end{array}$ \\
\hline $\mathrm{tb}_{23}$ & $\begin{array}{c}\text { Small products of transient } \\
\text { phase } \eta \text { ' and equilibrium phase } \\
\text { T precipitation are observed } \\
\text { inside the grains. Individual } \\
\text { phase } \eta \text { precipitation products } \\
\text { observed on grain boundaries }\end{array}$ \\
\hline
\end{tabular}

The above phases were identified using electron diffraction

\section{CORROSION-AND-STRESS RESISTANCE OF THE ALZN5MG2CRZR ALLOY}

Despite still existing numerous controversies, the literature overview makes it possible to describe mechanisms responsible for the process of crack incubation and propagation in $\mathrm{Al}-\mathrm{Zn}-\mathrm{Mg}$ alloys subjected to stress corrosion. The process 
of corrosion crack is, as a rule, intercrystalline in nature. This testifies to special role of changes taking place on grain boundaries and the areas adjacent to them (as a result of microstructure changes connected with chemical composition and heat treatment).

Fig. 7 presents mean percentage decrease of mechanical properties of the examined alloy $\mathrm{AlZn} 5 \mathrm{Mg} 2 \mathrm{CrZr}$ and the reference alloy PA47.

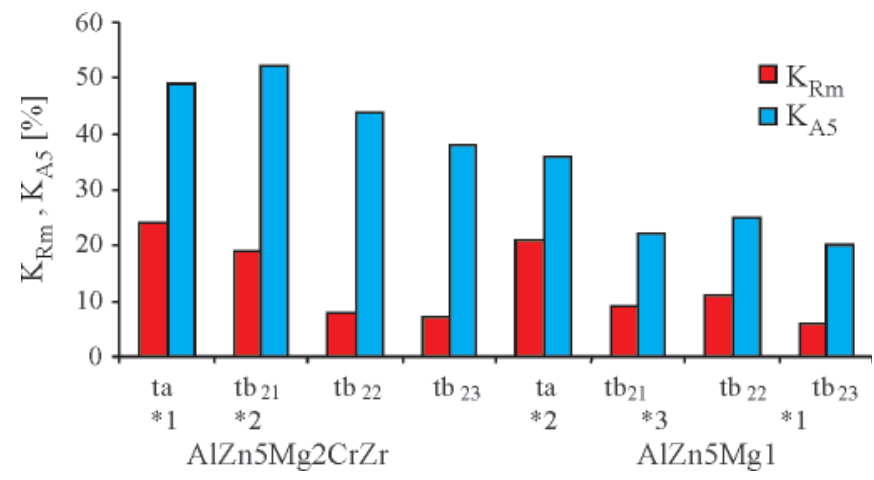

Fig. 7. Mean percentage reduction of the tensile strength $K_{R m}$ and plasticity $K_{45}$ of the AlZn5Mg2CrZr alloy and AlZn5Mg1 alloy, subjected to heat treatment after corrosion stress exposure in $3 \%$ water solution of $\mathrm{NaCl}$ during $1500 \mathrm{~h}$, where: $* X$ - number of samples, which were destroyed in time shorter than $1500 \mathrm{~h}$.

$\mathrm{K}_{\mathrm{Rm}}$ and $\mathrm{K}_{\mathrm{A} 5}$ coefficients were calculated using formulas 1 and 2 .

$$
\begin{aligned}
\mathrm{K}_{\mathrm{R}_{\mathrm{m}}} & =\frac{1}{\mathrm{n}} \sum \frac{\mathrm{R}_{\mathrm{mo}}-\mathrm{R}_{\mathrm{mk}}}{\mathrm{R}_{\mathrm{mo}}} 100 \% \\
\mathrm{~K}_{\mathrm{A}_{5}} & =\frac{1}{\mathrm{n}} \sum \frac{\mathrm{A}_{0}-\mathrm{A}_{\mathrm{k}}}{\mathrm{A}_{0}} 100 \%
\end{aligned}
$$

where:

$\mathrm{R}_{\text {mo }}$ - ultimate tensile strength, before corrosion exposure

$R_{m k}^{m o}$ - ultimate tensile strength, after corrosion exposure

$\mathrm{n}$ - number of samples

$A_{0}$ - plastic elongation of the tested material before corrosion exposure

$A_{k}$ - plastic elongation of the tested material after corrosion exposure

$\mathrm{K}_{\mathrm{Rm}}$ - mean percentage of the reduction of the ultimate tensile strength after corrosion exposure

$\mathrm{K}_{\mathrm{A} 5}$ - mean percentage of the reduction of the plastic elongation after corrosion exposure determined on test samples of $5 \mathrm{xg}$ gauge length.

\section{ANALYSIS OF THE EXAMINATION RESULTS}

The description of the AlZn5Mg2CrZr alloy microstructure in states $t a, t b, t b, t b$ is given in Table 5 , which that referring to the SWW zone width is collected in Table 4. The structure of the alloys was observed on thin foils in a transmission electron microscope Tesla-100Bs-500

The essence of Al-Zn-Mg alloy hardening consists in transferring the maximum possible number of zinc and magnesium atoms to the solid solution, and then collecting these atoms as precipitation products in the form of G-P zones. These (coherent) clusters have common matrix with the mother liquor. As the process of ageing continues, these clusters become partially or totally separated from the mother liquor, thus creating precipitation products having their own stoichiometric formula:

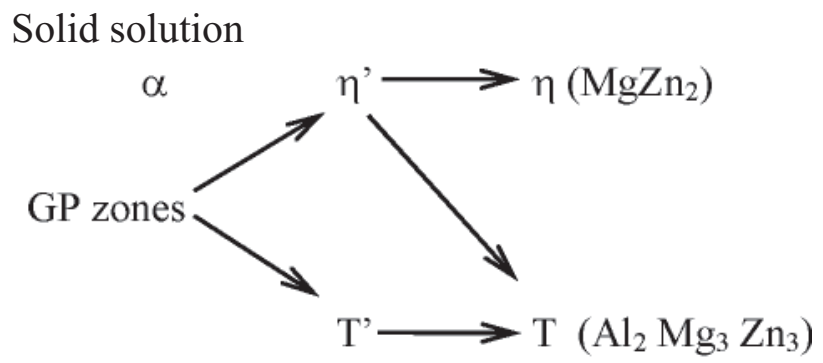

The rate of transformation of the G-P zones into transient phases $\eta$ ' and T' depends on the temperature of ageing. During this process the G-P zones cross over the critical point, i.e. the point, starting from which a GP zone either keeps increasing or, when it is not sufficiently large, dissolves in the matrix. The presence of the vacancies acts towards the increase of the G-P zones. Therefore the GP zones grow most slowly in the vicinity of grain boundaries, which act as vacancy traps $[6,8]$. During further ageing, the G-P zones which are situated near the boundaries and are smaller than the critical ones, dissolve in the matrix. As a result, the precipitation free zone (SWW) is formed near the boundary. This zone is often referred to as the solid solution zone (RS).

The natural ageing after supersaturation leads to the creation of a narrow RS zone, or to its complete absence. The longer the time of natural ageing, the narrower the RS zone.

The research activities confirmed the existence of a relation between the width of the RS zone and the resistance to stress corrosion. When the width of the RS zone increases, the resistance of the alloy to stress corrosion increases as well. The above analysis makes it possible to formulate the following general conclusions that (1) the heat treatment of the examined $\mathrm{AlZn} 5 \mathrm{Mg} 2 \mathrm{CrZr}$ alloy considerably affects its structure, and (2) the rate of cooling after supersaturation is a decisive factor determining the width of the SWW zone and the resultant resistance of the $\mathrm{AlZn} 5 \mathrm{Mg} 2 \mathrm{CrZr}$ alloy to stress corrosion.

\section{CONCLUSIONS}

As a result of the experiments we can conclude that the $\mathrm{AlZn} 5 \mathrm{Mg} 2 \mathrm{CrZr}$ alloy in tb state reveals better resistance to stress corrosion than in ta state, and therefore can be successfully used in shipbuilding. Moreover:

$O$ in the tb state, decreasing the cooling rate after solution heat treatment results in better stress corrosion cracking resistance

$O$ in the ta state, increasing the load results in significant strength reduction, to a lower level than in the tb state. This suggests that after heat treatment up to ta state the $\mathrm{AlZn} 5 \mathrm{Mg} 2 \mathrm{CrZr}$ alloy can be only employed in ship constructions which do not work under heavy stress corrosion cracking conditions.

The analysis of the results of examination of mechanical properties and corrosion resistance of the $\mathrm{AlZn} 5 \mathrm{Mg} 2 \mathrm{CrZr}$ alloy, and comparison with those of the AlZn5Mg1 alloy lead to the following conclusions:

Mechanical properties of Al-Zn-Mg alloys depend on (see Tab. 3):

- Chemical composition of the alloy. With increasing content of $\mathrm{Zn}+\mathrm{Mg}$ the mechanical properties become higher, while the plastic properties - slightly lower.

- Heat treatment of the alloy. The ta state reveals worse strength parameters $\left(\mathrm{R}_{\mathrm{m}}\right.$ in particular $)$ than the tb state. 
After comparing the $\mathbf{t b}_{21}$ and $\mathbf{t b}_{23}$ states it was found that the former leads to $\Delta \mathrm{R}_{\mathrm{m}}=20.6 \% ; \Delta \mathrm{R}_{02}=29.2 \%$ and $\Delta \mathrm{A}_{5}=-25 \%$, while, compared to the $\mathbf{t b}_{22}$ state, the tb $_{21}$ state gives $\Delta \mathrm{R}_{\mathrm{m}}=3.1 \%, \Delta \mathrm{R}_{0.2}=4.6 \%$ and $\Delta \mathrm{A}_{5}=-6.5 \%$. From the above we can conclude that increasing the cooling rate after solution heat treatment $\left(\mathbf{t b}_{21}-20^{\circ} \mathrm{C}\right.$ water cooling) results in the increase of strength parameters and in some reduction of plastic qualities.

The resistance of $\mathrm{Al}-\mathrm{Zn}-\mathrm{Mg}$ alloys to stress corrosion cracking depends on:

- Chemical composition of the alloy. With increasing content of $\mathrm{Zn}+\mathrm{Mg}$ the stress corrosion cracking resistance decreases.

- Heat treatment. In particular:

- In the ta state the $\mathrm{AlZn} 5 \mathrm{Mg} 2 \mathrm{CrZr}$ and $\mathrm{AlZn} 5 \mathrm{Mg} 1$ alloys show poor resistance to stress corrosion cracking and are prone to layer corrosion;

- Artificial ageing after supersaturation heat treatment (tb state) increases the resistance of the Al-Zn-Mg alloys to layer corrosion;

- Introduction of artificial ageing after supersaturation heat treatment (tb state), when accompanied by the reduction of the cooling rate, improves the resistance of the Al- $\mathrm{Zn}-\mathrm{Mg}$ alloys to the stress corrosion cracking;

- Heat treatment up to the $\mathbf{t b}_{22}$ and $\mathbf{t b}_{23}$ states improves the stress corrosion cracking resistance of the $\mathrm{AlZn5Mg} 2 \mathrm{CrZr}$ and $\mathrm{AlZn} 5 \mathrm{Mg} 1$ alloys.

The $\mathrm{AlZn} 5 \mathrm{Mg} 2 \mathrm{CrZr}$ alloy reveals better properties, as far as its application in shipbuilding is concerned, than the $\mathrm{AlZn} 5 \mathrm{Mg} 1$ alloy.

The microductility of the examined Al-Zn-Mg alloys strongly depends of chemical composition and metallurgical- and technological aspects, which are decisive upon the degree of their hardening by low-dispersion secondary-phase precipitation products.

\section{BIBLIOGRAPHY}

1. Jurczak W.: The effect of chemical composition and heat treatment on mechanical properties of Al-Zn-Mg alloys used in welded ship structures, and their resistance to stress corrosion. $\mathrm{Ph} . \mathrm{D}$. thesis, Gdansk University of Technology 1998 (in Polish)

2. Łagin I.: Struktura i swojstwa spłwow sistemy Al-Zn-Mg. W-wa 1982.

3. Gorczyca S. et al.: The effect of solid solution hardening and precipitation products action. Metalurgia 29, Proc. of Conference on Metallurgy and Founding 1981 (in Polish)

4. Kawabata T. Izumi O.: Acta Metall, Vol. 24, pp. 817-825, 2006

5. Bugłacki H.: The effect of heat treatment and chemical composition of binding materials on mechanical properties and stress corrosion of the AlZn5Mgl alloy in welded ship structures. Ph. D. thesis. Gdansk University of Technology 1981 (in Polish).

6. George F, Vander Voort: . Atlas of aluminium microstructures. 2005

7. George F. Vander Voort: Atlas of aluminium microstructures. 2006 by Taylor \& Francis Group, LLC

8. Łagin et. al: Struktura i swojstwa sptwow sistemy Al-Zn-Mg. W-wa 1982

9. Davis J.R.: Aluminium and aluminium alloys. Ohio 2004

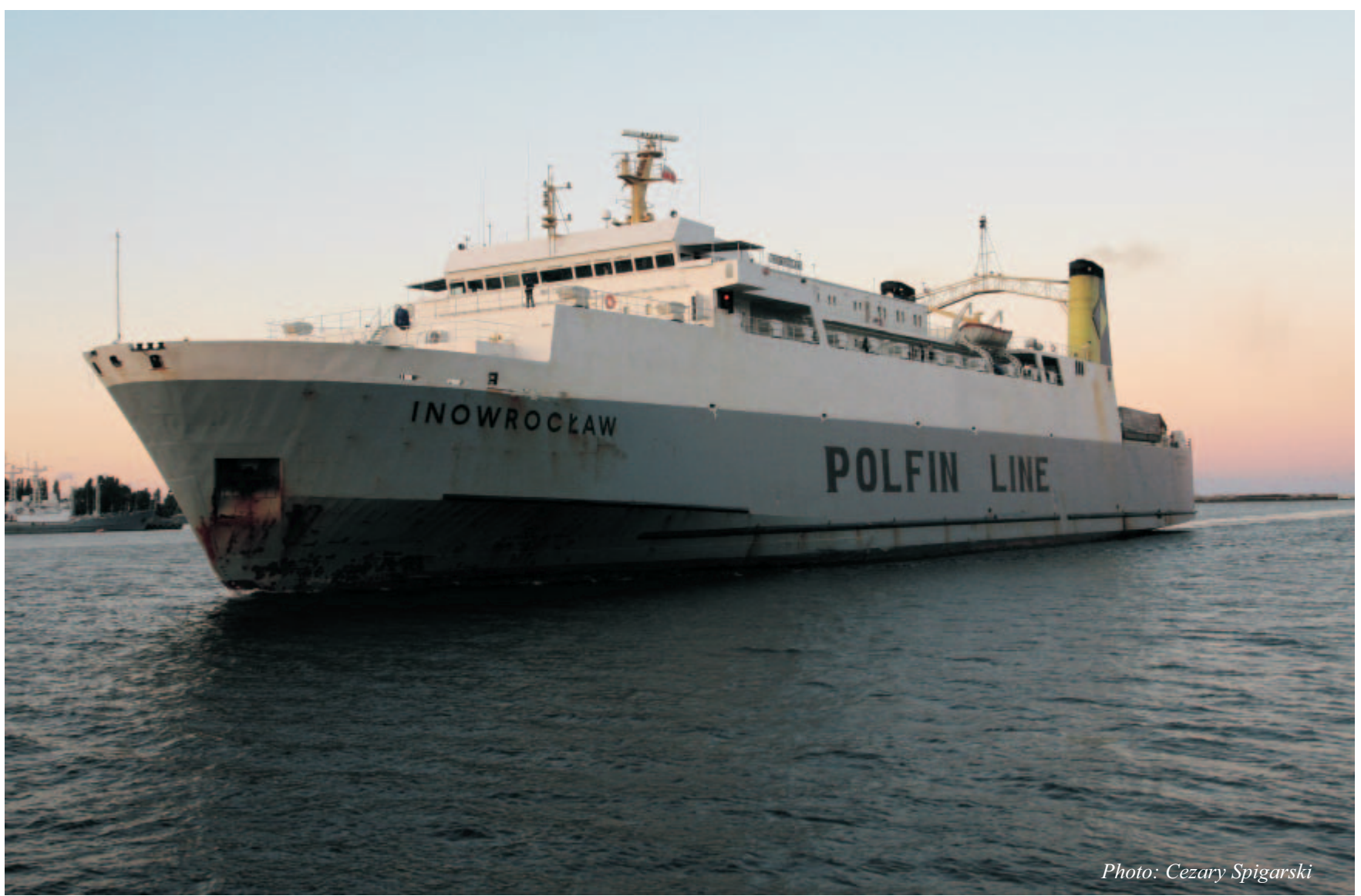

